\title{
The Level of Knowledge of the Pharmacy Staff at the Pharmacy Against the Implementation of PMK Number 9 of 2017
}

\author{
Ni Made Ayu Nila Septianingrum ${ }^{1 *}$, Fitriana Yuliastuti ${ }^{1}$, Widarika Santi Hapsari ${ }^{1}$ \\ ${ }^{1}$ Department of Pharmacy, Universitas Muhammadiyah Magelang, Magelang, Indonesia. \\ *Corresponding author. Email: nimadeayunila@ummgl.ac.id
}

\begin{abstract}
The purpose of this study was to determine the level of knowledge of pharmaceutical personnel about the implementation of PMK No. 9 of 2017 in pharmacies which includes the management of pharmaceutical, pharmaceutical services, human resources and infrastructure facilities. This research is analytic descriptive with cross-sectional survey sampling technique. The sample of this research is 37 pharmacies staff. The results obtained in the form of male respondents (18.9\%), Women (81.8\%), Pharmacists $(29.7 \%)$ and pharmacist assistant (70.3\%), length of work $<1-3$ years $(37.8 \%)$. Statistical test results state if the management variables of management pharmaceutical, pharmaceutical services, human resources, facilities and infrastructure are not related to the profession of pharmacy personnel, namely pharmacists or pharmacist assistant and the length of service. Also obtained results from the level of knowledge of each variable, namely pharmaceutical management (94.6\%), pharmaceutical services (78.4\%), facilities and infrastructure (81.8\%) included in the good category (> 76\%), while Human Resources (48.6\%) included in the less category $(<55 \%)$.
\end{abstract}

Keywords: pharmacy staff, PMK number 9 of 2017, management pharmaceutical, pharmaceutical services, human resources, facilities, infrastructure

\section{INTRODUCTION}

A pharmacy is a place where pharmacies services are carried out by pharmaceutical personnel as the main key [1]. Pharmaceutical services have benchmarks that can be used as guidelines for conducting pharmaceutical services perfectly [2]. Pharmacies must have standards that are used in pharmacy services at pharmacies. The current standard in Indonesia for pharmacies is PMK No. 9 of 2017 which focuses more on facilities and infrastructure to ensure patient safety [1]. Research conducted by Narendra, amounting to $97.87 \%$ of patients were very satisfied in the response dimension [3]. The dimension of responsiveness is carried out by pharmaceutical personnel, with satisfactory pharmaceutical services, high consumer confidence in pharmacies. Pharmacists as the vanguard in pharmacies must be able to give consumers confidence about the drugs they receive so that the expected results of patients taking these drugs is achieved. Kuncahyo in Mardiati [4] stated that Pharmacists who have a central role in pharmacies and are fully responsible for providing drug information to the public have not carried out their duties properly. Standards of pharmacy service in Pharmacy and Good Pharmacy Practices require the dominant role of a Pharmacist, especially Pharmacists in Community Pharmacy in terms of and abilities [5]. In order for pharmaceutical services to run well and equally, pharmaceutical staff as the main subject in pharmacies must understand the standards set by the government as outlined in PMK number 9 of 2017. Based on this background the researchers wanted to know the level of knowledge of pharmaceutical personnel on the implementation of PMK number 9 of 2017 in pharmacies to support patient safety in pharmaceutical services.

\section{METHOD}

This type of research is analytic descriptive with a sampling technique that is a cross-sectional survey. The instrument used was a questionnaire sheet based on PMK Number 9 of 2017 concerning Pharmacy. The types of questions in the questionnaire are closed questions with "Yes or No" answers. Data in the questionnaire used included name, length of work, profession, last education, while the variables used consisted of pharmaceutical management, pharmaceutical services, human resources, and facilities and infrastructure. The sample in this study were pharmaceutical workers who worked in pharmacies, as many as 37 respondents. Approved pharmaceutical workers are pharmacists and assistant pharmacist. Data obtained by distributing questionnaires to the pharmacy staff at the pharmacy which then sent descriptively by categorizing into good categories (> 76\%), Fair $(55 \%-75 \%)$, and enough $(<55 \%)$. Statistical tests are performed to see whether there is a relationship / variable relationship with the length of work and the relationship of respondents. After the data analysis is done, then it is poured in a descriptive form then draws conclusions. 


\section{RESULTS AND DISCUSSION}

\subsection{Respondent Characteristic}

In Table 1, the majority of respondents were women $(81.1 \%)$ with a length of work between less than 1 year to 3 years and working as a pharmacy assistant (70.3\%). Pharmacy assistants in this study are more numerous than pharmacists, this can be due to the pharmacies in the study site have not implemented "no pharmacy no service". Research conducted in DIY in 2010 stated that $70 \%$ of pharmacies in the city of Yogyakarta already have a Second Pharmacist [6]. The second pharmacist can replace the main pharmacist in the service at the pharmacy so that the pharmacies service can be carried out correctly [7].

Table 1 Respondent characteristic

\begin{tabular}{|clcc|}
\hline No. & Description & Total & \% \\
\hline 1. & Gender & & \\
& Female & 30 & 81.8 \\
& Male & 7 & 18.9 \\
\hline 2. & Duration Of Work & & \\
& < 1 Year & 14 & 37.8 \\
& 1-3 Years & 14 & 37.8 \\
& 3-5 Years & 3 & 8.2 \\
& > 5 Years & 6 & 16.2 \\
\hline 3. & Profession & & \\
& Pharmacist & 11 & 29.7 \\
& Pharmacist & 26 & 70.3 \\
& Assistant & & \\
\hline
\end{tabular}

\subsection{Pharmaceutical Service}

Pharmaceutical service which is one of the variables of this study, the results obtained are the level of knowledge of respondents included in the good category (78.4\%). Compared with the statistical test, if the length of work and profession does not correlate with pharmacy services running in pharmacy. Pharmaceutical services are something that must be done in health facilities, especially pharmacy. Because pharmacy services carried out by pharmacists can be a starting point for the prevention of abuse of drugs in the community. Providing good and correct drug information can help the community to minimize medication errors. Consumers who buy drugs at the pharmacies as much as $96 \%$ first read the drug label. Reading labels does not mean that consumers understand this. Consumers want as much information about the drug because it is related to health and their lives [8]. If a pharmacy worker can explain well about drugs consumed by consumers, then patients do not need to see the label again in consuming drugs because there is already trust in the pharmacy worker. Other research also mentions that if a drug information service room is very important to be owned by a health facility, with this space patients can be more open to ask questions and tell the therapy / disease that is or has been done [9]. So a pharmaceutical worker must be aware of his role as a public servant in the pharmaceutical field that can provide safety and best choice of drugs for consumers. to ensure this, pharmaceutical staff must increase their knowledge, one of them by attending seminars and training related to the latest medicines. According to Tjiptono (2004) in Putri [10] states that business services are vital objects that must be maintained so that consumers are satisfied. When a consumer feels his expectations are met by a business, consumers will definitely come back again and spread to others about it.

\subsection{Human Resources}

The level of respondent knowledge in the human resource variable is included in the category of enough $(48.6 \%)$, and the statistical test states if there is no correlation between the length of work and the type of profession on human resources at the pharmacies. Pharmacists and Pharmacy assistants are included in human resources at the pharmacies. This could be due to the lack of a pharmacist's presence at the pharmacy during opening hours. Research conducted in the city of Padang showed that as many as $58.67 \%$ of pharmacists were present in pharmacies [11]. That's mean that only half of the pharmacists who practice coming to the pharmacies so that pharmaceutical services that should be carried out by pharmacists are not carried out properly. The role of pharmaceutical services that should be carried out by pharmacists is no different when performed by Pharmacy assistants. The opportunity for medication errors is large and can have an impact on consumer confidence in the pharmacies. Research at Hospital X in the city of Surabaya shows that if drug information services are carried out to prevent disease $(47.2 \%)$, treatment becomes more optimal (30.6\%), and can reduce symptoms of the disease (19.4\%) [12]. Of course, the service will be excellent if it is done by a pharmacist. Other research that has been done in Bantul Yogyakarta stated that if the decision in drug selection by $34 \%$ is influenced by the intervention of pharmacists and $89 \%$ of patients want drug counselling especially drugs without prescription [8]. The existence of pharmacists during pharmacy opening hours is the main thing in pharmaceutical care.

\subsection{Management Pharmaceutical}

The level of knowledge about pharmaceutical management is included in the good category $(94.6 \%)$, but the statistical test states that the length of work and profession is not related to the management of pharmaceutical preparations at the pharmacy where the study was conducted. Pharmacy management is carried out in pharmacies, one of which will have an impact on the amount of existing drug stock. If the stock of the drug is moving slower than the fast moving one, the pharmacy will suffer losses and determine a buffer stock cannot be carried out [13]. Likewise with storage, if you do not use the system then errors in giving medicines to patients can occur (medication errors) due to wrong storage. Drug management includes ordering, receiving, storing, managing and destroying pharmaceutical preparations or prescriptions that have been going well. Purchasing drugs through authorized pharmaceutical distributors can support the application of good pharmaceutical services and prevent drug abuse. Pharmacy services are direct and responsible 
(LP3M) Universitas Muhammadiyah Magelang for financial assistance. We also thank the respondent for help during the research

\section{AUTHOR CONTRIBUTIONS}

Conceptualization (NMAN); Material research preparation (NMAN, FY, WSH); Methodology (NMAN, FY); Data collecting (WSH); Data analysis and visualization (NMAN, FY, WSH); Writing — original draft (NMAN); Presentation (NMAN).

\section{REFERENCES}

[1] Kementrian Kesehatan RI, "Peraturan Menteri Kesehatan Republik Indonesia Nomor 9 Tahun 2017," Jakarta, 2017.

[2] Kementerian Kesehatan Indonesia, "Peraturan Menteri Kesehatan Republik Indonesia Nomor 6 Tahun 2016 Tentang Formularium Obat Herbal Asli Indonesia.," pp. 31-48, 2016.

[3] M. P. Narendra, O. Skarayadi, and P. Adirestuti, "Analisis Tingkat Kepuasan Pelanggan Terhadap Pelayanan Di Apotek Kimia Farma Gatot Subroto Bandung," Kartika-Jurnal Ilm. Farm., vol. 5, no. 1, pp. 31-37, 2017.

[4] N. Mardiati, "Pelaksanaan Standar Pelayanan Kefarmasian Apotek Di Wilayah Kota Banjarmasin," Borneo J. Pharmascientech, vol. 01, no. 01, pp. 36-46, 2017.

[5] C. Wiedyaningsih and S. A. Kristina, "Kota Jambi Implementation Of Phamaceutical Care Standard In Jambi City's Pharmacies," Manaj. dan Pelayanan Farm., vol. 7, no. 73, pp. 83-96, 2017.

[6] N. F. Istiqomah and Satibi, "Evaluasi Implementasi Standar Pelayanan Kefarmasian Oleh Apoteker," Manag. dan Pelayanan Farm., vol. 2, no. 3, 2012.

[7] Kementerian Kesehatan RI, "Peraturan Pemerintah Republik Indonesia Nomor 51 Tahun 2009 Tentang Pekerjaan Kefarmasian,” Jakarta, 2009.

[8] S. F. Candradewi, S. A. Kristina, F. Farmasi, U. A. Dahlan, and J. P. Soepomo, "Gambaran pelaksanaan swamedikasi dan pendapat konsumen apotek mengenai konseling obat tanpa resep di wilayah Bantul," vol. 7, no. 1, pp. 41-52, 2017.

[9] P. S. Dianita, T. M. Kusuma, and N. M. A. N. Septianingrum, "Evaluasi Penerapan Standar Pelayanan Kefarmasian di Puskesmas Kabupaten Magelang
We are Thankful to Lembaga Penelitian, Pengembangan dan Pengabdian Masyarakat 
[13] A. Utari, "Cara Pengendalian Persediaan Obat Paten dengan Metode Analisis ABC, Metode Economic Order Quantity ( EOQ ), Buffer Stock dan Reorder Point ( ROP ) di Unit Gudang Farmasi RS Zahirah Tahun 2014 Progam Studi Kesehatan Masyarakat 2014 M / 1435 H,” Jakarta, 2014.

[14] Bpom, "Perka BPOM no 7 tahun 2016 tentang Pedoman Pengelolaan Obat-obat tertentu yang Sering Disalahgunakan," Bpom, pp. 1-16, 2016.

[15] Helni, “Tingkat Kepuasan Pasien Terhadap Pelayanan Apotek Di Kota Jambi,” Penelit. Univ. Jambi Seri Hum., vol. 17, no. 51, 2015. Mhs. Univ. Surabaya, vol. 2, no. 1, 2013.
[12] Y. E. Tjahyadi, "Studi Pelaksanaan Pelayanan
Informasi Obat di Rumah Sakit X Surabaya," J. Ilm

[11] P. City, D. Dominica, and D. P. Putra, "Pengaruh Kehadiran Apoteker Terhadap Pelayanan Kefarmasian di Apotek di Kota Padang," J. Sains Farm. dan Klin., vol. 3, no. 1, pp. 99-107, 2016. 